\title{
SUSTAINABILITY OF RICE PRODUCTION: A MALAYSIAN PERSPECTIVE
}

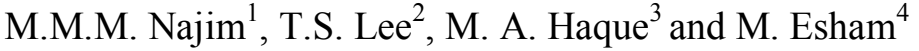

\begin{abstract}
As Asian rice demand is projected to increase by 30\% in 2010, a sustainable approach of rice production has become important. In order to fulfill the rice demand for the growing population and with the target rice self-sufficiency of $65 \%$, Malaysia has to increase its rice productivity. As the attainment of sustainability in rice farming is country and area specific, Malaysia has devised its own ways to achieve this goal within a prescribed time frame. The major problems faced by the rice sector have been identified and step-by-step solutions are sought through policy changes. Rice estates in Malaysia have already proven that commercial rice production is viable, economical and sustainable. FELCRA Seberang Perak, the first and largest rice estate in Malaysia, has proven the sustainability and viability of commercial rice farming by achieving a continuous cropping intensity of $200 \%$. The keywords to sustainable rice production are doubling yields, estatization and private corporate sector investments. The strategies to be devised must include getting investments to make the present non-lucrative business a profitable venture, whilst balancing the country's social obligation.
\end{abstract}

Key Words: Commercial rice production, Rice estate, Rice policy, Sustainability, Malaysia

\section{INTRODUCTION}

Rice growing is an old, heavily protected and subsidized industry. On a purely economic basis, Malaysia should not be growing any rice at all. It is just too expensive a venture. The productivity per worker involved in the business is anything but appalling. The alarming inefficiency is shown when we consider that 1200 Australian farmers who are growing 150,000 ha produce 1.275 million tones of rice compared with 150,000 paddy farmers in Malaysia producing 2.091 million tonnes from 676,700 ha (FAO, 2002). Currently, it is impossible for local rice to compete in international markets. For a similar grade of white rice, local production costs Ringgit Malaysian (RM) 1350(1US Dollar = 3.8 RM) per tonne, compared with the foreign cost of RM760. The noble cause of poverty eradication with less than two hectares per farmer is just infeasible to achieve its aim. A whole network of subsidies and agencies has been built around the paddy industry to keep farmers above the poverty line, a social obligation of the Malaysian government. This is coming to a cross road as Malaysia, on its way striving to be a developed nation by 2020 , sees efficiency and profitability in the agricultural sector crucial to her industrialization efforts.

The Malaysian government has set its rice self-sufficiency level at $65 \%$ and is capable of producing this amount at present. Thus, in order to fulfill the demand for the growing population, Malaysia has to sustain its production,

${ }^{1}$ Department of Agricultural Engineering, Faculty of Agriculture, University of Peradeniya, Peradeniya, 1 Sri Lanka.

${ }^{2}$ Faculty of Engineering, University Putra Malaysia, Serdang 43400, Selangor, Malaysia.

${ }^{3}$ Water Resources Planning Organization (WARPO) Ministry of Water Resource, House No. 130, Road No. 1, Banani, Dhaka-1213, Bangladesh.

${ }^{4}$ Faculty of Agricultural Sciences, Sabaragamuwa University of Sri Lanka, Belihuloya, Sri Lanka. 
but with an increase in rice productivity. This should come from the same acreage designated as the granary areas for rice production. In fact the acreage under cultivation has been under threat due to abandonment. Since rice is a strategic crop, it is essential to maintain a domestic production level for food security purposes and the target $65 \%$ of self sufficiency must be in tandem with the growing population. However, it must be borne in mind that droughts and flood may exacerbate the precarious food security. Getting farmers to grow rice when they could very well be making better money doing something else is indeed a challenge. For instance, in 1974, Thailand decided not to sell rice to Malaysia due to high demand, and thus she had to negotiate with China for supply. It was indeed a bitter experience for the Malaysian rice board.

Malaysia is a high cost producer and for this reason the National Agricultural Policy (1992-2010) does not aim for full self-sufficiency. The food import bill for Malaysia is RM 7 billion in 2002. The aim is to reduce this to RM 3 billion by 2005 and the target is to be a net exporter by 2010 for food produce. As one measure of countering the Asean Free Trade Area (AFTA) by 2005 and World Trade Organization (WTO), when subsidies to farmers are no longer permitted, the target is to achieve rice yields of 7 to 8 tonnes or more per hectare, from the current level at 4 to 5.5 tonnes per hectare. Just like Malaysia, some Asian countries are in the throes of expanding their industrial sector thus reducing paddy fields. The question then is, would there be sufficient rice supply in the world market for Malaysia to import? Malaysia's rice industry could also be completely wiped out with the entry of WTO and
AFTA, if it is not reorganized. The important weapon to battle these will be to change the mindset of farmers, increase technology transfer and attract private sector involvement.

Rice demand in Asia is projected to increase by $30 \%$ in 2010 as the regional economic slowdown forces more people to rely on the staple diet due to the higher cost in diversifying diets. In 1998, the International Rice Research Institute predicted that rice demand could reach 612 million metric tonnes in the next 12 years. Faced with a rising demand, rice supply is expected to decline because Asian governments are shaken by the turmoil of 1998 could less afford to invest in or maintain irrigation and other agricultural infrastructure. On the premise of this challenge, the rice production in countries traditionally with surplus will have to increase their yields, whilst subsistent countries will have to at least maintain production to satisfy their own needs. Against a background of rising population, fertile land constraints due to competition from other sectors, and dwindling or insufficient natural resources like water, a sustainable approach to rice production is thus becoming ever more important for the reasons delineated above.

\section{Sustainability and Productivity}

\section{Sustainability}

Sustainable development refers to development that meets the present needs without compromising the ability of future generations to meet their needs. Sustainability is a complex phenomenon viewed differently by various people that involves biology, ecology, economics, and socio-cultural and political 
considerations. A clear-cut definition that satisfies all is difficult.

Goodland and Ledec (1986) defined sustainable development as a pattern of social and structural economic transformations, which optimizes the economic and other societal benefits available in the present without jeopardizing the likely potential for similar benefits in the future. Sustainable rice farming could be defined as the process by which farmers manage soil and water relying, mainly on farm resources to enhance productivity and maintain it to meet farm and family needs, without adversely affecting the production environment. The work to attain agricultural sustainability, particularly with rice farming, requires careful adaptation of agricultural technologies to local social, economic, political, and ecological realities.

Sustainability is linked to a range of human problems that farmers face and it should be addressed in such a way that it would not disturb or disrupt the usually healthy rhythms of rural life in the case of Malaysia. Therefore, the devised strategies for sustainable rice farming should be country specific, and these should address each country's economic, political, environmental and social conditions and objectives. The strategies could take different forms and varying levels of sophistication, but must be based on a realistic analysis of diverse aspects of trade, science, and demographics. Political decision making from national leaders and enhanced international support for viable policies are the highest priorities concerned with sustainable increase in food production chain that will see to their fruitful conclusions.

\section{Productivity}

Maintaining higher levels of productivity for different aspects involved in rice production is important in the process of improving efficiency and sustainability. Productivity could be defined generally, as the optimum use of available resources to maximize returns. Farm efficiency is an important consideration in rice production, and is related to economics, the size of the farm, technological adaptations, and the overall levels of input usage in the agricultural sector. The constraints to production maximization are small and non economical size holdings, lack of capital, lack of irrigation and drainage facilities, inappropriate cropping and intensities, inaccessibility to markets, information and technological innovations, etc (Muhammad Alias, 1982).

The speed of completion of field operations will enhance the productivity. When irrigation and other facilities are adequate, the number of crops to be established will depend on the speed of field operations such as land preparation, crop establishment, and harvesting. These could only be achieved with the application of proper machinery provided with proper plot sizes. As labor scarcity increased with the industrialization, the improvement of labor productivity also became a major necessity in agriculture. The labor productivity improvement and a decrease in dependence on labor have become vital. This has lead to the rationalization of land ownership and size. 


\section{Malaysian Rice Production}

In Malaysia, lowland rice constitute $87 \%$ of rice cultivated and are mainly concentrated to eight granary areas and many mini granary areas. About $72 \%$ of the rice production in Malaysia is coming from the eight granary areas that are practicing double cropping. In peninsular West Malaysia, $76 \%$ of rice lands are provided with extensive irrigation and drainage facilities. Area under rice increased from 655000ha in 1985 to 670000 ha in 1995 , with an average annual growth rate of $0.2 \%$ and it expanded to 690000 ha in 1999 , a $0.75 \%$ annual increase (Mahmud, 2001; DOA, 2000). Anyway, in Peninsular Malaysia, paddy land has decreased from 447,624ha in 1984 to 425,080 ha in 1995 , a drop of $0.43 \%$. The national increase in paddy land is due to the expansion of land cultivated with paddy in Sabah, East Malaysia.

Over the 1985 - 1995 period, the country recorded an increase in average yield from $2.7 \mathrm{t} /$ ha to $3.2 \mathrm{t} / \mathrm{ha}$. Peninsular Malaysia recorded an average yield of $3.7 \mathrm{t} / \mathrm{ha}$ in 1995 . Total rice production increased from 1.7 million tonnes in 1985 to 2.1 million tonnes in 1995. The eight granary areas, which accounted for more than $70 \%$ of rice production, recorded an increased yield from $3.3 \mathrm{t} / \mathrm{ha}$ in 1985 to $4 \mathrm{t} /$ ha in 1995 (Table 1). The granary areas produced $64.3 \%$ of the national paddy production in 1985 and it increased to $68.8 \%$ in 1990 and $71.8 \%$ in 1995. Area planted and the yield from 1990 - 1994 in 8 granary areas and 74 mini-granary areas increased by $2.6 \%$ and $13.4 \%$ respectively. Over the 1985-1995 period, domestic production accounted for about $77 \%$ of the total domestic consumption. In 1995, importation of rice amounted to 427,570 t valued at RM 356.1 million. The import bill of paddy in 2000 was RM 691 million and it increased by $1.3 \%$ in 2001 to $\mathrm{RM} 700$ million (Ministry of Finance, 2001).

Table 01: Average paddy yields in Malaysia

\begin{tabular}{ccccccc}
\hline & \multicolumn{2}{c}{ All Seasons } & \multicolumn{2}{c}{ Main Season } & \multicolumn{2}{c}{ Off Season } \\
\cline { 2 - 6 } Year & $\begin{array}{c}\text { Area planted } \\
(\mathrm{ha})\end{array}$ & $\begin{array}{c}\text { Average yield } \\
(\mathrm{kg} / \mathrm{ha})\end{array}$ & $\begin{array}{c}\text { Area planted } \\
(\mathrm{ha})\end{array}$ & $\begin{array}{c}\text { Average yield } \\
(\mathrm{kg} / \mathrm{ha})\end{array}$ & $\begin{array}{c}\text { Area planted } \\
(\mathrm{ha})\end{array}$ & $\begin{array}{c}\text { Average yield } \\
(\mathrm{kg} / \mathrm{ha})\end{array}$ \\
\hline 1985 & 654974 & 2665 & 463078 & 2465 & 191896 & 3148 \\
1986 & 650875 & 2640 & 457681 & 2476 & 193194 & 3027 \\
1987 & 658954 & 2469 & 453828 & 2458 & 205126 & 2491 \\
1988 & 671755 & 2525 & 464495 & 2433 & 207260 & 2732 \\
1989 & 664137 & 2625 & 443795 & 2417 & 220342 & 3045 \\
1990 & 680647 & 2769 & 457906 & 2554 & 222741 & 3211 \\
1991 & 683640 & 2818 & 458688 & 2605 & 224952 & 3251 \\
1992 & 672753 & 2992 & 445214 & 2890 & 227539 & 3191 \\
1993 & 693434 & 3035 & 459869 & 2861 & 233565 & 3377 \\
1994 & 698624 & 3061 & 454600 & 2856 & 244024 & 3443 \\
1995 & 672787 & 3162 & 433778 & 2944 & 239009 & 3558 \\
1996 & 685468 & 3251 & 444223 & 2991 & 241245 & 3730 \\
1997 & 690975 & 3068 & 439958 & 2849 & 251017 & 3450 \\
1998 & 674404 & 2883 & 433684 & 2685 & 240720 & 3240 \\
1999 & 692389 & 2641 & 444306 & 2593 & 248083 & 3565 \\
\hline
\end{tabular}

(Source: Department of Agriculture, Malaysia (2000).) 
Chang (1983) reported that with a population growth rate of $2.7 \%$ per annum, an estimated additional 45,000 tonnes of rice is required each year just to maintain the current per capita consumption levels. The rice consumption in Malaysia is projected to increase from 1.8 million tonnes in 1995 to 2.3 million tonnes in 2010 (Mahmud, 2001). There are prospects for the development of rice industry in Malaysia in order to cater to the increased demand. With improvement in domestic incomes and a rising standard of living, the production of affordable quality rice can be a step in the right direction.

\section{Sustainability issues and challenges}

\section{Challenges for sustainability}

Although rice production showed a positive growth, paddy production faces many challenges which are correlated to economic, social, acceptance of technology, and conformity to field infrastructure etc. Identification of these challenges are important to achieve a sustainable rice production system in Malaysia. Farm size, labor shortage, lack of capital and infrastructure and traditional production systems are few constraints need to be addressed.

Farmers discontinue rice farming in some situations because of the availability of better economic alternatives such as employment in industrial sector. As younger generation of farming community attain better education levels and as the industrial sector has provided more promising and attractive employment, the agricultural sector is facing an acute energetic labor force shortage. This has created the need to reduce labor supply for farming operations.
Land available for agriculture is becoming limited by industrialization, urbanization, and expansion of residential areas so that the need arises to maximize land productivity. There is a need to strengthen the competitiveness of Malaysian agriculture. The implementation of the agreements under the WTO and the Common Effective Preferential Tariff (CEPT) will create greater competition. Small holders need to be transformed into a more commercialized sector as efficiency gaps are still substantial between smallholder and estate sector. The smallholder sector continues to experience problems of low productivity and uneconomic holding size so that are vulnerable to closure, unless drastic measures are taken. Therefore, to ensure above poverty levels, the land per settler was increased by decreasing the number of settlers in newly established projects, like Seberang Perak project.

In all major paddy-growing areas, most field operations are performed using machinery. But, there are some constrains in the use of machinery. These constraints are related to hardware, infrastructure and organization that are interrelated. Embi et al. (1985) reported that $21 \%$ of the total expenditure on rice production is for the purchase and running of farm machinery, if the machinery is to be owned by the management of a paddy estate. This figure does not include the machine operator wages, repair and maintenance, and other facilities needed for machinery. Experiences with different crops in various countries have shown contracting out or hire services from private sector are more efficient than those operated by public agencies or cooperatives. The existence of private rental services can avoid over investments in machinery 
(Ellis, 1992). Contracting out heavy farm jobs to specific single task operators is now common in Malaysia.

Farm gate price of paddy in Japan and Taiwan is about 8 times the world market price (Rijk, 1993). Unless production per unit area increases, the farming system will not be able to pay for more advanced technology. The solution for this is to consolidate land into larger and more efficient units.

\section{Economy of size}

Smallholders on an average, have a farm size of 1.06ha. Houghton (1994) surveyed individual rice farmers in peninsular Malaysia and found that given the small size of farms, only $15 \%$ of income was earned from rice cultivation. Another $27 \%$ of income came from other farm activities while the rest was earned through off farm activities. In the state of Negeri Sembilan, a considerable amount of irrigated paddy lands were abandoned due to the uneconomical plot sizes (Muhammad Alias, 1982).

Inadequately sized uneconomical plots are often seen as one of the greatest obstacles to increase rice productivity. Small plots hinder the operation of machinery and optimum use of other inputs. Fragmentation of land (due to subdivision through inheritance according to Islamic rules) in some states and areas due to population pressure, industrialization and urbanization has reduced the size of land owned or operated by a single farmer. The units have become so small that these are no longer economically viable, and even not meeting their subsistence levels. When the size of the field decreases, mechanization of activities also becomes uneconomical.

\section{Labor shortage}

In 1970, the agricultural sector in Malaysia provided $50 \%$ of the employment, while in 1984 this was reduced to $34 \%$. With the rural youth attaining higher education standards and the availability of more rewarding and comfortable jobs in the cities, it has resulted in a higher labor shortage in the unattractive agricultural sector. Competition from numerous oil palm estates aggravates the situation further. Increasing movement of younger generation or whole farmer families to the urban centers permanently has complicated the issue of sustainability of rice production in Malaysia.

Agricultural employment is anticipated to decline by $0.2 \%$ per annum over 1992 - 2010. The Ministry of Finance (2001) reported that the employment in agriculture sector is expected to decline by $0.7 \%$ during 2001. Abdul Aziz and Nasir (1993) reported that the younger workers of 20 years and less have decreased from $8.39 \%$ in 1984 to $3.82 \%$ in 1991 while older workers of 51 to 55 years increased from $6.59 \%$ in 1984 to $9.2 \%$ in 1991. By $1982,57 \%$ of the registered paddy lands in Negeri Sembilan, were abandoned because of labor shortage, low productivity of the lands, high off-farm income, water shortage, and multiple land ownership (Mohd Ariff and Thiran, 1982).

In traditional rice production, labor cost represents about $79 \%$ of the total cost of production per hectare. As availability of labor for agricultural activities reduced, rice production systems are mechanized. In mechanized farming, it could be reduced to $15 \%$ when land preparation, seeding and harvesting are mechanized (Ayob, 1986). In order to save labor, direct seeding has become the most suitable crop establishing method, 
together with mechanization for almost all the field activities from land preparation to harvesting.

\section{Lack of Capital}

Capital availability is an important factor for sustainable rice production. When the farmers are subsistence farmers, their capital availability will determine their success in improving or maintaining better production levels. As the labor cost, machinery rentals and other input costs are higher, they inevitably tend to give up rice farming because of low profitability. In few cases, individuals or private enterprises have rented many such neglected lands and started rice farming pooling lands to an estate. They could do this because of their ability to mobilize capital.

\section{Traditional Vs Modern (Consolidated) Paddy Land}

Rice farming has been viewed as being economically less rewarding, especially when a farmer is just operating a small plot of about 1 to 2 ha. Traditional paddy lots are 0.1 to 0.5 ha separated by a network of bunds, which serve as ownership boundary, water control structure, and a path. Modern rice farms have bigger plots with all the infrastructures available in each farm lot, in a systematical order, to facilitate mechanization, transportation, cultural practices and efficient and easy water management.

Devendra and Abdul Aziz (1994) reported that in Beranang, the shifting from traditional transplanting to direct seeding with a reorganization of land and labor resources have brought higher levels of farm productivity and income. They also found that the income in a technologically advanced paddy farm is doubled that of a traditional farm. Transformation from traditional to modernized paddy production took place step by step, with the support of the Malaysian government. These changes were done in order to satisfy and sustain the rice production of the country.

Sardar Ali (1993) reported that the canal, drain and road densities before $1960 \mathrm{~s}$ in the rice fields were at $2 \mathrm{~m} / \mathrm{ha}$, which is one of the factors delaying the farming activities. The yield was low, at about $1 \mathrm{t} / \mathrm{ha}$. From $60 \mathrm{~s}$ to mid $70 \mathrm{~s}$, the government investment on farm infrastructure and new water resources development paved the way for rice double cropping. As the need to stick to schedules immerged, the presaturation and the land preparation was shortened, with higher canal, drain and road density of about $10 \mathrm{~m} / \mathrm{ha}$ and use of tractors for land preparation and lorries to transport the harvest. From mid $70 \mathrm{~s}$ to the end of $80 \mathrm{~s}$, with industrialization, the opportunity cost of labor increased in the manufacturing sector encouraging urban migration creating an acute labor shortage for the agricultural sector. Therefore, all labor-intensive field operations had to be mechanized. The roads were improved to withstand heavier machinery and fields were resized to maximize machine efficiency. In order to cope up with the mechanization, the canal, drain and road densities were improved to 30 to $35 \mathrm{~m} / \mathrm{ha}$ (Sardar Ali, 1993). During the 80s, the government introduced estatized rice farming where most of the farming activities are mechanized. The machine requirement was met by contracting out heavy activities. These systems are designed with high canal, drain and road densities together with uniform sized rectangular plots. From the 90s, the farm access road 
conditions and densities were improved to cater for the increased heavy machinery (up to 10 tonnes) movement. With the introduction of direct seeding and machinery for harvesting created the need for on-farm improvements such as land leveling for better water control, increased drain densities to increase the soil bearing capacity by quick drainage, and farm plot rearrangement for more efficient machine operations.

\section{Policy}

As poverty incidences in Malaysian rice sector were $88.1 \%$ in 1970 , the rice policy during 1971 - 1990 was to improve farm household income through productivity. The government took steps such as increase of farm gate price of paddy, free fertilizer (100\% subsidized), and the improvement of irrigation water management facilities and infrastructure. Diminished farmer interests in paddy growing resulted in much more idle rice land. The Government of Malaysia therefore reviewed its policy for rice selfsufficiency, gradually reducing the self-sufficiency level to $65 \%$ with rice growing to be concentrated in the major granary areas. The National Agricultural Policy (NAP) in 1980 emphasized new land development and consolidation of uneconomic sized lands. The policy was to improve the productivity while sustaining the agriculture in the long run. The NAP of 1992 to 2010 has given the main emphasis as improvement of productivity, efficiency, and competitiveness. This NAP was reviewed in 1997 and the main emphasis was given to income maximization through optimal use of resources.
The Sixth Malaysia (1991-1995) plan has emphasized the importance of mechanization and labor saving techniques. The Malaysian government's objective for agriculture is maximization of farm productivity and income. This is achievable through mechanization by lowering production cost and increasing labor and land productivity. The Seventh Malaysia Plan (1996-2000) contained plans to improve competitiveness in food commodities and this effort continues to be emphasized in the Eighth Malaysia Plan (2001-2005). The food sector is to be liberalized to allow for greater market efficiency.

As the Malaysian government was aware about the problems faced by rice industry, a number of policies such as fertilizer and price subsidies were instituted to ensure food security. Rice smuggling was further exacerbated when the Agriculture Ministry has taken over the enforcement authority from the Domestic Trade and Consumer Affairs Ministry, to regulate supply by curbing smuggling activities (Malaysia-Thailand border) in May 2002. The Malaysian government not only identified the proper actions but also implemented others with success in the rice sector. This included the mobilization of necessary investments locally and internationally, making difficult political decisions on resource allocation, land planning, and land reforms by policy changes. For example, the World Bank and the Malaysian government together invested on the Federal Land Consolidation and Rehabilitation Authority (FELCRA) Seberang Perak project, where the government of Malaysia made the policy changes required for land planning, land reform and resource allocation. 
In April 2002, the government has ordered the formation of a special task force to review the national paddy and rice policies following fears that the local rice industry may collapse upon the implementation of the AFTA in 2005. The review is needed given the current price difference between local rice (RM550 per tonne) on the wholesale market and imported rice (RM350 per tonne). There is an obvious need to save at least RM200 per tonne for the local rice to remain competitive or risk losing out all together. This is indeed a tall order and best achieved by increasing yields for the current levels of inputs.

To improve efficiency in the processing and marketing of rice, the National Paddy and Rice Board (established as a statutory body in 1971) was made a corporate body renamed as BERNAS in 1994. With a 15-year right to import rice from January 1996, it became one of the players in the market with commercial interests while having to handle social responsibilities such as managing farmers' subsidies, ensuring sufficient supply of rice and national stockpiling, being a last minute buyer at a guaranteed minimum floor price of RM550, and providing soft loans. It has become profit driven. BERNAS urged the government to raise the price of rice in the market so that farmers will have the incentive to plant better quality rice that fetches better prices. Its contention is that deregulated price fixing will allow the industry to achieve efficiency by itself. It also hopes to achieve better efficiency by consolidating the rice wholesale sector. However, monopoly critics have asked the government to open up the market and allow more importers so that consumers get a better deal.

\section{Estatization}

Acute labor shortage and rapid conversion of rice lands to more profitable ventures have added pressure to meet the national rice production. As a result, many changes such as land consolidation and redistribution have taken place in the last three decades in Malaysia. One of the most promising changes is the reorganization of rice areas into larger production units either by entrepreneurs renting out of several small units of farm land or by farmer groups or associations operate pooled rice areas, or commercial enterprises develop and manage large areas with bigger land parcels or plots formed into large and continuous paddy fields.

Large-scale operations are no longer subsistent entities but commercial ventures, which are not only economically viable, but also socially acceptable, environmentally friendly and sustainable systems. One of these large-scale rice-producing areas is the Seberang Perak rice estate managed by the FELCRA where each participant is allocated 1.2 ha of rice and 1.2 ha of oil palm that are centrally managed as estates. All farming activities are mechanized in this rice estate and most of the field operations are contracted out rather than owning machinery. Some 20,000 ha of the Muda Agricultural Development Authority region are being managed under the group farming or as mini estates. These two concepts have brought about better yields, superior standard of crop management and reduced cost of production because farmers act as a group for contracting tractors and combined harvesters, dealing with transporters, buyers and millers. Following the success of these projects, other rice farming projects, the Endau-Rompin, Kahang and the 
Gedong projects in Sarawak were implemented, based on estate concepts, which were pioneered by the private sector. With these private companies in the fold, there was a proposal for the government to consider giving some form of incentives like tax relief for paddy firms since they lose out in terms of government subsidies specially the free fertilizer subsidy given to small scale farmers.

By estatization, the cultivation is intensified where the plot sizes are resized in order to make it a more productive unit. Estate management has the advantage of direct and overall control of the whole area under the estate. This type of management saves labor through overall planning or labor utilization and mechanization. Staggered cultivation due to individual farmer's preference would be minimized by estatization, where the direct seeding and other operations are done with machinery, so that the works are completed within a scheduled time period. The crop establishment has to be shifted to direct seeding from transplanting in order to cope up with labor shortages and to minimize staggering. Large and continuous paddy fields have facilitated efficient movement of machinery and attraction of contractors for lower rates. The centralized management, for example FELCRA Seberang Perak, is responsible for applying resource saving technologies, which are capable of overcoming the scarcities of inputs and services, quickly accepting and adapting recommendations and instructions from research centers. Furthermore, FELCRA has enough capital for all the farming activities through its centralized management. FELCRA farmers are getting a good income through daily wages for their labor as well as dividends.
Many paddy field activities are critical and needs timely implementation so that strict adherence to the schedules is vital and prerequisite for sustainable attainment of high yield and cropping intensity. The successful mechanization needs careful designing and planning of farm lot layout for efficient machinery movement, efficient and adequate irrigation and drainage systems. All the constraints pertaining to the mechanization have been overcome in FELCRA Seberang Perak by selecting proper machinery with efficient service providers, proper planning of the plot sizes with access roads and other facilities, and a centralized management to co-ordinate all work and make sure the strict adherence to the schedules. Close adherence to the cropping schedule is possible in the project area mainly because of the contracting out of the farming activities. This freed the management of the project to concentrate on other crucial activities within the production system. The locating of two rice mills in the scheme makes accessibility for rice milling activities conducive and efficient minimizing transportation needs. The project obtained yields (4.8t/ha/season) above the national average yields $(3.2 \mathrm{t} / \mathrm{ha} /$ season $)$ and an uninterrupted $200 \%$ cropping intensity from 1986 to 2002. The experience gained from achieving the $200 \%$ cropping intensity is utilized to shift to $250 \%$ intensity for beyond 2002 .

\section{CONCLUSION}

Strategies for sustainable rice farming should be country specific, and should address each country's economic, political, environmental and social conditions and objectives. Political decision making from national leaders and enhanced international support for 
viable policies are the highest priorities concerned with sustainable rice production. Labor effective ways, new technologies, and better ways of involving the private sector and farmer reorganizations have become catalysts in achieving sustainability in rice farming.

Industrialization in Malaysia created an acute labor shortage in agricultural sector. Decrease in dependence on labor and improving labor productivity is achieved through rationalization of land ownership and size together with the adoption of innovations and technology. Malaysia has identified eight granary areas and produces about $70 \%$ of the national production. Granary areas are converted from labor intensive to highly mechanized double cropping areas. Mechanization has replaced most of the farming activities and hired contractors mainly supply the machinery together with trained operators for farm operations.

Lack of capital and infrastructure also has accelerated the negligence of rice lands. One way to enhance farmers' position in existing paddy schemes is to help them to be self sufficient by setting up a corporation with their own mills and distribution network. Therefore, small holders are being transformed into a more commercialized sector because of the efficiency gaps between the smallholder and one based on an estate concept. They will then have a share in the whole process of rice production.

Through policy formulations, Malaysia has taken steps to modernize rice farming in order to address the problems faced by the rice sector. These changes were introduced step by step in Malaysia from late 1960s. The major changes were improvement of infrastructure, enlargement of land parcels by land consolidation, reorganization of the size and shape of individual lots, introduction of mechanization, subsidies, and the creation of rice estates. Estatization of rice farming, making rice farming a commercial venture, has shown tremendous successes. Because of the proven profitability of collective farming, private sector also has started investing on rice estates.

\section{References}

Abdul Aziz, A.R. and S. Mad Nasir (1993) Agricultural Labor force in Malaysia: Outlook and Implications. In Mechanization towards increased productivity. Proceeding of the national conference on Mechanized Agriculture. pp. 23 34. Editors: S. Ayob, O. H. Seng, and T. I. Ailin, Malaysian Agricultural Research and Development Institute, Malaysia.

Ayob, S. (1986) Mechanization of Malaysian food crops production: some considerations. In Proceeding of the Seminar on Mechanization in Agriculture in Malaysia. pp. 33 - 50. Editors: S.A.K. Abdul Azis, M. Abu Bakr, and H.Y. Chan, Agricultural Institute of Malaysia, Kuala Lumpur, Malaysia.

Chang, C. C. (1983) Current trends in water management for paddy cultivation. In Engineering towards progressive agriculture, Proceeding of a national symposium at Universiti Pertanian Malaysia. pp. 187 - 202. Editors: A. Fakhrul Razi, A.A. Abang Abdullah, M.S. Mohd. Amin, and A. Desa, Faculty of Agricultural Engineering, Universiti Pertanian Malaysia, Selangor, Malaysia. 
Devendra, P.Y., and A. R. Abdul Aziz (1994) Credit, technology and paddy farm production: A case study of Tanjong Karang and Beranang, Malaysia. The Developing Economics, 32(1), pp. $66-85$.

DOA, (2000) Statistics on Paddy. Department of Agriculture Malaysia. URL: http://agrolink.moa.my/doa/indexBl.html, Accessed on $11^{\text {th }}$ October 2002.

Ellis, F. (1992) Agricultural policies in developing countries. Wye Studies in Agricultural and Rural development. Cambridge University Press. Cambridge.

Embi, Y. A. W. Cheong and Y. Mohd. Shahrin (1985) Large-scale rice farming in Malaysia. Teknologi Padi 1(2), pp. 47 - 53.

FAO, (2002). Selected Indicators of Food and Agriculture Development in AsiaPacific Region 1992-2002, Food and Agriculture Organization of The United Nations, Regional Office for Asia and the Pacific, Bangkok.

Goodland, R. and G. Ledec (1986) Neoclassical economics and Principles of Sustainable Development. Office of Environment and Scientific Affairs, World Bank, Washington DC.

Haughton, J. (1994) Tackling Rural Poverty: An Assessment of alternative strategies for mixed-farming areas in peninsular Malaysia. The Developing Economies 32(3), pp. $256-278$.

Mahmud, Y. (2001) Crop Diversification in Malaysia. In Crop diversification in the Asia-Pacific Region. Editors: M.K. Papademetriou and F.J. Dent, Food and Agricultural Organization Regional Office, Bangkok, Thailand.

Ministry of Finance (2001) Economic Report 2001/2002. Ministry of Finance, Kuala Lumpur, Malaysia.

Mohd. Ariff, H. and N. Thiran (1982) Utilization of idle paddy land in Negeri Sembilan. Journal of Pertanika 5(1), pp. $105-113$.

Muhammad Alias, R.M.A. (1982) Productivity in Agriculture. Land Development Digest 5(1), pp. $1-14$.

Rijk, A.G. (1993) Towards mechanized agriculture in a rapidly industrializing economy. In Mechanization towards increased productivity, Proceeding of the National Conference on Mechanized Agriculture. Editors: S. Ayob, H.S. Ooi, and T.I. Ailin, Malaysian Agricultural Research and Development Institute, Malaysia.

Sardar Ali, R. (1993) Farm infrastructure for mechanized agriculture. In Mechanization towards Increased productivity, Proceedings of the National Conference on Mechanized agriculture. pp. 87 - 95. Editors: Ayob, S., O.H. Seng and T.I. Ailin, Malaysian Agricultural Research and Development Institute and Agricultural Institute of Malaysia, Malaysia. 